\title{
Do Labor Unions Affect Stock Price Crash Risk?
}

\author{
Hamdi Ben-Nasr ${ }^{1}$, Abdullah Al-Dahmash ${ }^{2} \&$ Hatem Ghouma ${ }^{3}$ \\ ${ }^{1}$ Finance Department, College of Business Administration, King Saud University, Riyadh, Saudi Arabia \\ ${ }^{2}$ MSF program, College of Business Administration, King Saud University, Riyadh, Saudi Arabia \\ ${ }^{3}$ The Gerald Schwartz School of Business, St. Francis Xavier University, NS, Canada \\ Correspondence: Hamdi Ben-Nasr, Finance Department, College of Business Administration, King Saud University, \\ Riyadh, 71115, 11587, Saudi Arabia. Tel: 966-54-704-4326. E-mail: hbennasr@ksu.edu.sa
}

Received: December 31, 2014

Accepted: January 17, 2015

Online Published: March 9, 2015

doi:10.5430/ijfr.v6n2p11

URL: http://dx.doi.org/10.5430/ijfr.v6n2p11

\begin{abstract}
This paper examines the influence of labor unions on stock price crash risk. Using a large sample of U.S. firms over the period 1984-2013, we provide the evidence that labor unions increase the likelihood to experience future stock price crashes. This finding is consistent with the argument that firms facing strong labor unions tend to report lower accounting information, in order to preserve bargaining power when negotiating contracts with labor unions. Further, we find that the adverse effects of labor unions on stock price crash risk are less pronounced for firms with strong external monitoring mechanisms, such as high institutional ownership and high analyst coverage.
\end{abstract}

Keywords: stock crash risk, extreme outcomes, labor unions

\section{Introduction}

The role of labor protection in corporate finance has recently drawn the interest of numerous scholars. One strand of literature examines the role of labor protection in determining corporate decisions. For instance, De Angelo and De Angelo (1991) examine the impact of labor union on corporate dividends. In the same vein, Klasa, Maxwell, Ortiz-Molina (2006) explore the effect of labor union on cash holdings. Atanassov and Kim (2009) examine the relative influence of labor vis-à-vis investors on the nature of the restructuring decisions made by poorly performing firms. Acharya, Baghai, and Subramanian (2010) examine the impact of labor union on corporate innovation. More recently, Chen and Chen (2013) study the link between labor union and the sensitivity of investment to cash-flow. Several other studies (e.g., Hillary, 2006; Bova, 2013; Chung, Lee, Lee and Sohn, 2014) examine the impact of labor union on the quality of financial reporting. Another strand of literature, investigate the economic outcomes of labor protection. For example, Faleye, Mehrotra, and Morck (2006) find that when labor has a weight in the firm's corporate governance, workers might adopt strategies that push the firm policies away from stockholders' value maximization. In particular, their study documented lower new capital expenditures, less risk appetite, slower growth and lower total factor productivity for firms where employees have a greater voice in corporate governance. Consistent with this point of view, Chen, Kacperczyk, and Ortiz-Molina (2012) show that strong labor union is associated with a lower cost of debt. Furthermore, Chen, Kacperczyk, and Ortiz-Molina, (2011) examine the impact of labor union on the cost of equity. Strong labor protection is associated with higher labor adjustment costs (e.g., Serfling, 2013). Indeed, wages are sticky and layoffs are more costly when labor protection is strong. In such a case, firing employees wouldn't be an easy task even if it is economically optimal. Higher labor adjustment costs reduces operating flexibility, hence increases the cost of equity. Consistent with this argument, Chen et al (2011) show that firms from highly unionized industries are penalized by a higher cost of equity.

In this study, we extend the aforementioned researches by analyzing the relationship between labor unions and stock price crash risk. We conjuncture that in firms where unions are strong, managers tend to reduce the bargaining power of these unions by adopting a less transparent disclosure policies which might result in higher likelihood to experience stock price crash.

Moreover, previous studies (e.g., An and Zhang, 2013; Callen and Fang, 2013; Kim and Zhang (2013), etc.) suggest that large institutional ownerships and higher analyst coverage could mitigate information asymmetry and decrease the probability to hoard bad news. Hence, we further explore the role that institutional ownership and analyst coverage could play in the relationship between labor unions and stock price crash risk. To test our hypotheses, we use a sample of 73,543 U.S. firm-year observations and a patent data covering the period from 1984 to 2013. Specifically, we use firm-year unionization rate, calculated by multiplying the industry-level unionization rate by the 
number of employees deflated by total assets, as a proxy for labor union. In line with prior literature (e.g. Chen, Hong and Stein, 2001; Jin and Myers, 2006), we use two proxies for stock price crash risk: (i) the negative conditional skewness of weekly return (NCSKEW) and (ii) down-to-up volatility (DUVOL). Our results suggest that stock price crash risk increases in labor union strength. This finding is consistent with the conjecture that firms facing strong labor unions tend to report lower accounting information, in order to preserve bargaining power when negotiating contracts. This behavior, resulting in more opaque financial reporting, increases the likelihood to experience stock price crash. We also find that the adverse effects of labor union on stock price crash risk are less pronounced for firms with strong external monitoring mechanisms, such as high institutional ownership and high analyst coverage.

These findings contribute to the existing literature twofold. First, it contributes to the understanding or the drivers of stock price crash risk by focusing on the role of non-financial and traditional stakeholders, namely labor unions. Second, it contributes to the ongoing literature on labor unions (e.g., Hillary, 2006; Klasa et al., 2006; Chen, Kacperczyk, and Ortiz-Molina 2011, 2012; Chen, Chen, and Liao 2011; Bova, 2013; Chung et al., 2014, among others) by shedding more lights on the roles and objectives of these unions and their places within the firm's overall corporate strategies.

The rest of the paper is organized as follows. In section 2, we review the literature and outline our testable hypothesis. Section 3 describes data and empirical design. Section 4 presents the empirical results and robustness tests. Section 5 concludes.

\section{Related Literature and Hypotheses}

Previous studies suggest that rents that unionized employees can extract from their firms are higher compared to those that non-unionized employees can extract (Bova, 2013). In fact, unionized employees have greater bargaining power when negotiating contracts (Hirsch 1991, 2008) mainly due to the threat to go on strikes, which might result in disrupting production and damaging the reputation of the firm in the labor market if the agreements are not reached (Hamm, Jung, and Lee, 2013). Given that, managers of firms with unionized employees have incentives to take strategic actions in order to minimize the rents that these employees may extract. Prior research provides large support for this point of view. For instance, De Angelo and De Angelo (1991) show that firms with unionized employees tend to cut dividends in order to impede labor to extract more resources. Similarly, another strand of literature (e.g., Bowen, Ducharme, and Shores, 1995; Cullinan and Knoblett, 1994; D’Souza, Jacob, and Ramesh, 2000) shows that firms with unionized labor strategically choose accounting methods that results in lower transparency, hence reduces the ability of employees to extract more rents. In the same vein, Hillary (2006) shows that strong labor unions are associated with higher bid-ask spread increases, hence higher information asymmetry. This finding suggests that managers of firms with unionized employees are reluctant to share information on the prospects of the firm with employees in order to preserver bargaining power when negotiating contracts. Klasa et al. (2006) show that the managers of firms with unionized employees tend to hold more cash than non-unionized peers in order to shelter firm resources form rent-seeking labor unions. More recently, research by Farber, Hsieh, Jung and Yi (2012) suggests that higher levels of union strength are associated with lower level of accounting conservatism (i.e., lower earnings quality). Hamm, Jung, and Lee (2013) argue that strong labor unions increase the incentives of managers to smooth incomes. Specifically, they argue that firms with unionized employees tend to manage earnings upwards (downwards) in bad (good) times in order reduce the ability of labor unions to extract firm resources. Consistent with this argument, they show that income smoothing activities (i.e., discretionary income smoothing and R\&D investment adjustments) are positively associated with labor unions strength. Bova (2013) argues that firms facing strong labor union may undertake actions that allow them to intentionally miss the expectations of analysts, hence hide corporate resources that may be extracted by labor unions. To do so, they may manipulate either the expectations of analysts or the reported earnings. Consistent with this view, the author shows that unionized firms are more likely to miss the analyst earnings consensus. Chung et al. (2014) argue that disclosure frequency for Korean firms is negatively related to labor union strength, also supporting the view that managers of unionized firms tend to obscure accounting information in order to preserve bargaining power.

Poor disclosure quality, in our case due to unions' pressures, might result in stock price crashes. Indeed, extant empirical research provides empirical evidence suggesting opaque financial reporting is associated with higher stock price crash risk. For example, Jin and Myers (2006) show that firms from countries with high financial reporting opacity are more likely to experience stock price crash. Similarly, Hutton et al. (2009) show that stock price crash risk may be affected by earnings management. In fact, he shows the tendency of firms to manage earnings upwards in bad times to a point beyond which they can no longer do it, leads to stock prices to crash when a cascade of bad information is revealed. In the same vein, DeFond, Hung, Li and Li (2012) show that the mandatory adoption of International Financial Reporting Standards (IFRS) in the European Union, which reduces financial reporting opacity, hence reduces stock price crash risk. Additionally, Kim and Zhang (2013) provide evidence that accounting 
conservatism (i.e., timelier recognition of economic losses versus economic gains) weakens the ability of managers to conceal bad news, which reduces stock price crash risk.

The above arguments suggest that firms facing strong labor unions tend to report lower accounting information, in order to preserve bargaining power when negotiating contracts, which lead to opaque financial reporting. Given that financial reporting opacity increases the likelihood to experience stock price crash, we expect that stock price crash risk increases in labor union strength.

\section{Data Description and Empirical Design}

\subsection{Stock Price Crash Risk Proxy}

Following previous researches (Kim and Zhang, 2011a, 2011b, and 2013; Kim, Li, and Li, 2014), we use two different firm-specific crash risk proxies based on Jin and Myers's (2006) market model. Specifically, we regress the weekly stock return of each firm in our sample on the value weighted market return in current week as well as two weeks forward and backward using the following model:

$$
r_{i, t}=\alpha_{i}+\beta_{1, i} r_{m, t}+\beta_{2, i} r_{m, t-1}+\beta_{3, i} r_{m, t-2}+\beta_{4, i} r_{m, t+1}+\beta_{5, i} r_{m, t+2}+\varepsilon_{i, t}
$$

where $r_{i, t}$ is the stock return for firm $i$ in week $t$, and $r_{m, t}$ is the return of CRSP's value-weighted market index in week $t$, and $\varepsilon_{i t}$ is an error term. In line with previous studies, the lead and lag returns are introduced to account for non-synchronous trading. Since stock prices reflect mixed information, including both firm-level and market-level, we use the regression model (1) to decompose these information and only keep the firm-level component $\left(\varepsilon_{i, t}\right)$ to analyze the crash risk. Economically, stock prices are more informative when stock returns become less correlated with past, current, and future market returns. The natural logarithm of one plus the residual from equation (1), i.e. $\log \left(1+\varepsilon_{i, t}\right)$ is our proxy for firm-specific weekly return for firm $i$ in week $t\left(W_{i, t}\right)$.

Our first proxy for stock price crash risk is the negative conditional firm-specific skewness of weekly return (NCSKEW). We calculate NCSKEW by dividing the negative of the third moment of firm firm-specific weekly returns, $W_{i, t}$, for each sample year by the standard deviation of firm-specific weekly returns raised to the third power. Following Kim et al. (2014), we calculate NCSKEW for each firm $i$ at year $t$ as:

$$
\operatorname{NCSKEW}_{i, t}=-\left[n(n-1)^{3 / 2} \sum W_{i, t}^{3}\right] /\left[(n-1)(n-2)\left(\sum W_{i, t}^{2}\right)^{3 / 2}\right]
$$

where $W_{i, t}$ is as previously defined and $n$ is the number of weekly return observations during year $t$. A higher negatively skewed return distribution (i.e., a higher value for NCSKEW) indicates a higher crash risk.

The second proxy for stock price crash risk is the down-to-up volatility (DUVOL) calculated as the natural logarithm of the standard deviation of weekly-stock returns $W_{i, t}$, during the weeks in which $W_{i, t}$ is lower than its annual mean ("down" weeks) over the standard deviation of weekly-stock returns $W_{i, t}$, during the weeks in which $W_{i, t}$ is higher its annual mean ("up" weeks). Specifically, DUVOL for each firm $i$ at year $t$ is calculated as:

$$
D U V O L_{i, t}=\log \left\{\left[\left(n_{u}-1\right) \sum_{D O W N} W_{i, t}^{2}\right] /\left[\left(n_{d}-1\right) \sum_{U P} W_{i, t}^{2}\right]\right\}
$$

where $n_{u}$ is the number of "up" weeks and $n_{d}$ is the number of "down" weeks. The higher the DUVOL, the higher the crash risk.

\subsection{Labor Unions Proxy}

Our labor unions proxy is the firm-year unionization rate $(U N I O N)$. This measure is widely used in the accounting and finance literature (e.g., Bova, 2013; Chen and Kacperczyk, 2011; Chen, Kacperczyk, and Ortiz-Molina, 2012; Chung, Lee, Lee and Sohn, 2014, among others). The firm-year unionization rate is calculated by multiplying the industry-level unionization rate by the number of employees deflated by total assets. Industry-level unionization rates come from Hirsch and Macpherson (2003)'s updated database of Union Membership and Coverage. (Note 1) 


\subsection{The Sample}

We collect firm and market stock returns from The Center for Research in Security Prices (CRSP). First, we calculate our two proxies for crash risk for the period from 1983 to 2013. (Note 2) Then, we merge our estimates for stock price crash risk with: (i) labor union data over the period from 1983 to 2013 from Hirsch and Macpherson (2003)'s updated database of Union Membership and Coverage (ii) financial data from COMPUSTAT, (iii) analyst coverage data from the Institutional Brokers' Estimate System (I/B/E/S) summary files and (iv) institutional ownership data from Thomson Financial Institutional Holdings (13f) Database. Finally, we winsorize all firm-level variables at the $1^{\text {st }}$ and the $99^{\text {th }}$ percentiles to mitigate the effect of outlier observations. Thus, we end-up with a sample of 73,543 firm-year observations for the period from 1984 to 2013.

\subsection{Empirical Models}

To examine the impact of labor unions on stock price crash risk, we estimate several specifications of the following regression model:

$$
C R A S H_{i, t}=\delta_{0}+\delta_{1} U_{N I O N} N_{i, t-1}+\delta_{2} \text { CONTROLS }_{i, t-1}+\gamma_{t}+\varepsilon_{i t}
$$

Following the recent literature on stock price crash risk (e.g., Kim and Zhang, 2011a, 2011b, and 2013; Kim et al., 2014), we include in CONTROLS the following variables that may affect crash risk: the natural logarithm of a firm's market value at year $t-1\left(S I Z E_{i, t-1}\right)$ to control for firm size, the ratio of long-term debt for a firm $i$ at year $t-1$ over total assets for firm $i$ at year $t-1\left(L E V E R A G E_{i, t-1}\right)$ to control for financial risk, the market-to-book ratio $\left(M B_{i, t-1}\right)$ at year $t-1$ to control for growth opportunities, the ratio of net income at year $t-1$ over total assets at year $t-1 R O A_{i, t-1}$ ) to control for firm profitability, the change in turnover ratio ( $D T U R N O V E R_{i, t-1}$ ) calculated as the difference between the average monthly turnover at $t-1$ and the average monthly turnover at $t-2$ to control for the intensity of differences of opinion among investors, the average of firm-specific weekly returns over the fiscal year to control for past returns $\left(R E T_{i, t-1}\right)$. Chen et al. (2001) show that firms with high past returns have more probability to crash. Thus, we include the standard deviation of the weekly stock returns at year $t-1\left(S I G M A_{i, t-1}\right)$ to control for stock return volatility and the absolute value of Dechow and Dichev's (2002) measure of abnormal accruals at year $t-1 \quad\left(A Q_{i, t-1}\right)$, as modified by Ball and Shivakumar (2005) to control for earnings management. Moreover, we include industry and year dummies to control for the industry and fixed effects in all the regressions. Finally, we adjust standard errors for the effect of non-independence by clustering on each firm.

\section{Empirical Results}

\subsection{Descriptive Statistics}

Table 1 reports descriptive statistics on the variables used to estimate equation (4). The average (median) of $N C S K E W_{i, t-1}$ is equal to -0.006 (-0.096) and the average (median) of $D U V O L_{i, t-1}$ is equal to $-0.030(-0.059)$. These numbers are comparable to those reported in prior related literature (e.g., Kim and Zhang, 2011a, 2011b, and 2013; Kim et al., 2014). The average (median) of our proxy for labor union, the firm-year unionization rate (UNION) is $0.094(0.062)$.

Table 1. Descriptive statistics

\begin{tabular}{|c|c|c|c|c|c|c|}
\hline Variable & $\mathbf{N}$ & Mean & Median & $\begin{array}{l}\text { Standard } \\
\text { deviation }\end{array}$ & Q1 & Q3 \\
\hline$N C S K E W_{t}$ & 73,543 & -0.006 & -0.096 & 1.071 & -0.554 & 0.366 \\
\hline$D U V O L_{t}$ & 73,543 & -0.030 & -0.059 & 0.443 & -0.309 & 0.200 \\
\hline$U_{N I O N} N_{t-1}$ & 73,543 & 0.094 & 0.062 & 0.098 & 0.021 & 0.131 \\
\hline$S I Z E_{t-1}$ & 73,543 & 5.127 & 5.020 & 2.113 & 3.548 & 6.606 \\
\hline$N C S K E W_{t-1}$ & 73,543 & -0.002 & -0.104 & 1.301 & -0.579 & 0.370 \\
\hline$D U V O L_{t-1}$ & 73,543 & -0.026 & -0.063 & 0.527 & -0.320 & 0.202 \\
\hline
\end{tabular}




\begin{tabular}{lllllll} 
LEVERAGE $_{t-1}$ & 73,543 & 0.196 & 0.165 & 0.182 & 0.021 & 0.317 \\
$M B_{t-1}$ & 73,543 & 2.757 & 1.881 & 2.981 & 1.151 & 3.217 \\
ROA $_{t-1}$ & 73,543 & -0.007 & 0.038 & 0.205 & -0.034 & 0.090 \\
DTURNOVER $_{t-1}$ & 73,543 & -0.021 & -0.009 & 0.751 & -0.247 & 0.206 \\
RET $_{t-1}$ & 73,543 & -0.002 & -0.001 & 0.006 & -0.004 & 0.002 \\
$S I G M A_{t-1}$ & 73,543 & 0.037 & 0.032 & 0.022 & 0.021 & 0.047 \\
$A Q_{t-1}$ & 73,543 & 0.144 & 0.082 & 0.215 & 0.040 & 0.161 \\
\hline
\end{tabular}

This table presents descriptive statistics for the variables used in our multivariate regression analysis to examine the impact of labor union on stock price crash risk for a sample of 73,543 firm-year observations for the 1984-2013 period. Descriptions and sources of these variables are provided in the Appendix.

Table 2 reports Pearson correlation coefficients between the stock price crash risk proxies, our labor union proxy, and the control variables. The correlation coefficients that are significant at the $1 \%$ level are highlighted in bold. For instance, we find that $U N I O N_{i, t-1}$ are significantly and positively correlated at the $1 \%$ level with $N C S K E W_{i, t}$, suggesting a positive relationship between the negative skewness in stock returns and the unionization rate. We also find that $U N I O N_{i, t-1}$ is significantly and positively correlated at the $1 \%$ level with $D U V O L_{i, t}$, suggesting a positive relationship between the two variables as well. As for the control variables, we report several significant correlations which are consistent with prior related crash risk literature. In fact, both of $N C S K E W_{i, t}$ and $D U V O L_{i, t,}$ are positively correlated at the $1 \%$ level with $\operatorname{SIZE}_{i, t-1}, M B_{i, t-1}, R O A_{i, t-1}, D T U R N O V E R_{i, t-1}$, and $R E T_{i, t-1}$. Additionally, both $N C S K E W_{i, t}$ and $D U V O L_{i, t}$, are negatively correlated at the $1 \%$ level with $S I G M A_{i, t-1}$, suggesting a significant relationship between the volatility of the stock returns and the probability to experience stock price crash. We also report low correlation coefficients between our labor union proxy and the control variables, thus mitigating multicollinearity concerns that could affect our regression results.

Table 2. Pearson correlations

\begin{tabular}{|c|c|c|c|c|c|c|c|c|c|c|c|c|}
\hline Variable & 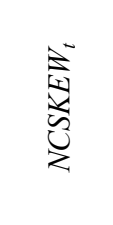 & 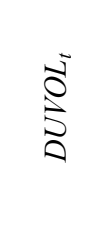 & $\frac{\mathfrak{I}}{\grave{z}}$ & $\underset{\sim}{\mathbb{N}}$ & $\begin{array}{l}\sum^{2} \\
\vdots \\
\vdots \\
\vdots \\
z\end{array}$ & \begin{tabular}{l}
\multirow{J}{J}{} \\
$\vdots$ \\
5 \\
0
\end{tabular} & 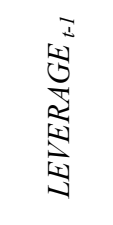 & $\sum_{z}^{I}$ & $\underbrace{I}_{2}$ & 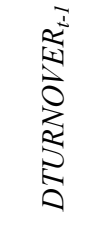 & $\frac{I}{2}$ & 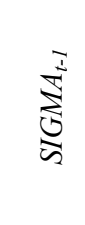 \\
\hline$D U V O L_{t}$ & 0.948 & & & & & & & & & & & \\
\hline$U N I O N_{t-I}$ & 0.026 & 0.024 & & & & & & & & & & \\
\hline$S I Z E_{t-1}$ & 0.035 & 0.031 & 0.005 & & & & & & & & & \\
\hline$N C S K E W_{t-1}$ & 0.032 & 0.031 & 0.005 & 0.960 & & & & & & & & \\
\hline$D U V O L_{t-1}$ & 0.048 & 0.035 & 0.019 & 0.083 & 0.064 & & & & & & & \\
\hline$L E V E R A G E_{t-1}$ & 0.000 & 0.006 & 0.140 & -0.008 & -0.002 & -0.035 & & & & & & \\
\hline$M B_{t-1}$ & 0.038 & 0.029 & -0.099 & 0.026 & 0.013 & 0.194 & -0.049 & & & & & \\
\hline$R O A_{t-1}$ & 0.070 & 0.067 & 0.098 & 0.070 & 0.062 & 0.254 & -0.019 & -0.171 & & & & \\
\hline \multicolumn{13}{|l|}{ DTURNOVER } \\
\hline$t-1$ & 0.027 & 0.024 & 0.009 & 0.014 & 0.008 & 0.076 & 0.017 & 0.086 & 0.056 & & & \\
\hline$R E T_{t-1}$ & 0.032 & 0.033 & 0.024 & -0.395 & -0.425 & 0.142 & -0.019 & 0.032 & 0.153 & 0.074 & & \\
\hline$S I G M A_{t-1}$ & -0.052 & -0.054 & -0.111 & 0.154 & 0.137 & -0.488 & -0.003 & 0.038 & -0.323 & 0.026 & -0.238 & \\
\hline$A Q_{t-1}$ & 0.003 & 0.004 & -0.106 & -0.014 & -0.014 & -0.081 & -0.084 & 0.150 & -0.183 & 0.028 & -0.021 & 0.141 \\
\hline
\end{tabular}




\subsection{Labor Unions and Stock Price Crash Risk}

Table 3 reports the OLS regression results obtained by regressing our two proxies for stock price crash risk on $U N I O N$. In both of the two models reported in this table, we control for industry fixed-effects and year fixed-effects. We also cluster standard errors at the firm-level. The results reported in Model 1, in which we use the negative skewness in stock returns (NCSKEW) as dependent variable to proxy for stock price crash risk, provide evidence that supports our hypothesis, suggesting that highly unionized firms are more likely to experience stock price crash. As it can be seen from the model, the coefficient of $U N I O N_{i, t-1}$ is positive and statistically significant at the $1 \%$ level. Moreover, the proxy for the reporting quality (AQ) is significantly and positively related to the crash risk. These two combined results are consistent with the argument that more employee-unionized firms tend to report lower accounting information, in order to preserve bargaining power when negotiating contracts with labor unions. This behaviour would lead to higher likelihood of stock price crash.

Model (2) reports our results of the impact of labor union on stock price crash risk when we use the down-to-up volatility as a proxy for stock price crash risk. As we can observe, the coefficient for UNION is also positive and significant at the $1 \%$ level, corroborating our earlier finding. This finding suggests that highly unionized firms have higher down-to-up volatility.

As for the control variables, we report several significant coefficients that are consistent with our predictions. The coefficients for $S I Z E_{i, t-1}, R O A_{i, t-1}, M B_{i, t-1}, D T U R N O V E R_{i, t-1}, R E T_{i, t-1}$ and $A Q_{i, t-1}$ are positive and significant at the $1 \%$ level, across all specifications, suggesting that larger firms, more profitable firms, firms with higher growth opportunities, with higher changes in turnover ratio, and higher returns in the past and higher absolute value of Dechow and Dichev's (2002) measure of abnormal accruals (i.e., lower earnings quality) have higher stock price crash risk. Additionally, we find a negative significant coefficient at the $1 \%$ level for $S I G M A_{i, t-1}$, implying that firms with higher stock return volatility have higher stock price crash risk.

Table 3. Multivariate results

\begin{tabular}{|c|c|c|c|c|}
\hline \multirow{2}{*}{ Variable } & \multicolumn{2}{|c|}{ NCSKEW } & \multicolumn{2}{|c|}{ DUVOL } \\
\hline & Coefficient & $\mathrm{p}$-value & Coefficient & $\mathrm{p}$-value \\
\hline UNIONt-1 & $0.187 * * *$ & $<0.01$ & $0.067 * * *$ & $<0.01$ \\
\hline$S I Z E_{t-1}$ & $0.007^{* *}$ & 0.01 & -0.001 & 0.270 \\
\hline$N C S K E W_{t-1}$ & $0.037 * * *$ & $<0.01$ & & \\
\hline$D U V O L_{t-1}$ & & & $0.037 * * *$ & $<0.01$ \\
\hline LEVERAGE ${ }_{t-1}$ & -0.021 & 0.37 & 0.000 & 0.970 \\
\hline$M B_{t-1}$ & $0.016 * * *$ & $<0.01$ & $0.006 * * *$ & $<0.01$ \\
\hline$R O A_{t-1}$ & $0.286^{* * *}$ & $<0.01$ & $0.113 * * *$ & $<0.01$ \\
\hline DTURNOVER $R_{t-1}$ & $0.027 * * *$ & $<0.01$ & $0.011 * * *$ & $<0.01$ \\
\hline$R E T_{t-1}$ & $5.426 * * *$ & $<0.01$ & $2.344 * * *$ & $<0.01$ \\
\hline$S I G M A_{t-1}$ & $-1.599 * * *$ & $<0.01$ & $-0.818 * * *$ & $<0.01$ \\
\hline$A Q_{t-1}$ & $0.079 * * *$ & $<0.01$ & $0.037 * * *$ & $<0.01$ \\
\hline Intercept & -0.138 & 0.130 & -0.138 & \\
\hline Year fixed effect & Yes & & Yes & \\
\hline Industry fixed effect & Yes & & Yes & \\
\hline Observations & 73,543 & & 73,543 & \\
\hline R-squared & 0.017 & & 0.017 & \\
\hline
\end{tabular}

This table presents regression results of the impact of labor union on stock price crash risk. The full sample includes a sample of 73,543 firm-year observations for the 1984-2013 period. All regressions include industry and year dummies to control for industry and year fixed-effects, respectively. Descriptions and data sources for the regression variables are provided in the Appendix. We adjust standard errors for the effect of non-independence by clustering on each firm. ${ }^{* *}, * *$, and $*$ denote statistical significance at the $1 \%, 5 \%$, and $10 \%$ levels, respectively. 


\subsection{Further Analysis on the Role of Institutional Ownership and Analyst Coverage}

In this section, we control for additional control variables that may affect stock price crash risk. Particularly, we investigate the role that the presumed external disciplinary mechanisms, namely institutional ownership and analyst coverage, might have in the above documented relationship between labor union and crash risk. Prior literature suggests that large stake holdings by long term institutional investors are associated with lower stock price crash risk (e.g., An and Zhang, 2013; Callen and Fang, 2013). Moreover, the number of analysts following the company might also mitigate information asymmetry and decrease the probability to hoard bad news (Kim and Zhang (2013)).

To test these hypotheses, we include in the regressions reported in table 4 the percentage of institutional ownership $(I O)$ and the number of analysts following a firm $(A C O V)$ as additional explanatory variables. The results reported in Models 1 and 3 where (IO) was added as an explanatory variable show that the coefficient for UNION remains positive and significant at the $1 \%$ level, corroborating our earlier findings.

In Models (2) and (4) of Table 4, we control for analyst coverage using the natural logarithm of one plus the number of analysts following a firm $(A C O V)$ from $I / B / E / S$ summary files. The results show that the coefficient for $A C O V$ is negative and significant (at 10\% level only), in line with Kim and Zhang (2013), suggesting that higher analyst coverage mitigates information asymmetry, hence decreases the probability to hoard bad news.

Table 4. Additional controls

\begin{tabular}{|c|c|c|c|c|c|c|c|c|}
\hline \multirow{4}{*}{ Variable } & \multicolumn{4}{|c|}{ NCSKEW } & \multicolumn{4}{|c|}{ DUVOL } \\
\hline & \multicolumn{2}{|c|}{$I O_{t-1}$} & \multicolumn{2}{|c|}{$A C O V_{t-1}$} & \multicolumn{2}{|c|}{$I O_{t-1}$} & \multicolumn{2}{|c|}{$A C O V_{t-1}$} \\
\hline & Coefficient & $\mathrm{p}$-value & Coefficient & $\mathrm{p}$-value & Coefficient & p-value & Coefficient & $\mathrm{p}$-value \\
\hline & \multicolumn{2}{|c|}{ (1) } & \multicolumn{2}{|c|}{ (2) } & \multicolumn{2}{|c|}{ (3) } & \multicolumn{2}{|c|}{ (4) } \\
\hline UNIONt-1 & 0.187 & $<0.01$ & $0.190 * * *$ & $<0.01$ & $0.067 * * *$ & $<0.01$ & $0.068 * * *$ & $<0.01$ \\
\hline$S I Z E_{t-1}$ & $0.007 * *$ & 0.01 & $0.010 * * *$ & $<0.01$ & 0.000 & 0.26 & -0.001 & 0.87 \\
\hline$N C S K E W_{t-1}$ & $0.037 * * *$ & $<0.01$ & $0.037 * * *$ & $<0.01$ & & & & \\
\hline$D U V O L_{t-1}$ & & & & & $0.038 * * *$ & $<0.01$ & $0.037 * * *$ & $<0.01$ \\
\hline$L E V E R A G E_{t-1}$ & -0.022 & 0.37 & -0.021 & 0.37 & 0.000 & 0.97 & 0.000 & 0.98 \\
\hline$M B_{t-1}$ & $0.016^{* * *}$ & $<0.01$ & $0.016^{* * *}$ & $<0.01$ & $0.006^{* * *}$ & $<0.01$ & $0.006^{* * *}$ & $<0.01$ \\
\hline$R O A_{t-1}$ & $0.286^{* * *}$ & $<0.01$ & $0.287 * * *$ & $<0.01$ & $0.113 * * *$ & $<0.01$ & $0.113 * * *$ & $<0.01$ \\
\hline DTURNOVER $R_{t-1}$ & $0.027 * * *$ & $<0.01$ & $0.027 * * *$ & $<0.01$ & $0.010 * * *$ & $<0.01$ & $0.011 * * *$ & $<0.01$ \\
\hline$R E T_{t-1}$ & $5.427 * * *$ & $<0.01$ & $5.407 * * *$ & $<0.01$ & $2.337 * * *$ & $<0.01$ & $2.344 * * *$ & $<0.01$ \\
\hline$S I G M A_{t-1}$ & $-1.598 * * *$ & $<0.01$ & $-1.582 * * *$ & $<0.01$ & $-0.811 * * *$ & $<0.01$ & $-0.817 * * *$ & $<0.01$ \\
\hline$A Q_{t-1}$ & $0.079 * * *$ & $<0.01$ & $0.079 * * *$ & $<0.01$ & $0.037 * * *$ & $<0.01$ & $0.037 * * *$ & $<0.01$ \\
\hline$I O_{t-1}$ & 0.000 & 0.47 & & & 0.000 & 0.18 & & \\
\hline$A C O V_{t-1}$ & & & $-0.001 *$ & 0.09 & & & $-0.001 *$ & 0.08 \\
\hline Intercept & -0.138 & 0.13 & -0.148 & 0.11 & -0.055 & 0.16 & -0.051 & 0.13 \\
\hline Year fixed effect & Yes & & Yes & & Yes & & Yes & \\
\hline Industry fixed effect & Yes & & Yes & & Yes & & Yes & \\
\hline Observations & 73,543 & & 73,543 & & 73,543 & & 73,543 & \\
\hline R-squared & 0.017 & & 0.017 & & 0.017 & & 0.017 & \\
\hline
\end{tabular}

This table presents regression results of the impact of labor union on stock price crash risk while introducing additional control variables. The full sample includes a sample of 73,543 firm-year observations for the 1984-2013 period. All regressions include industry and year dummies to control for industry and year fixed-effects, respectively. Descriptions and data sources for the regression variables are provided in the Appendix. We adjust standard errors for the effect of non-independence by clustering on each firm. ${ }^{* * *},{ }^{* *}$, and ${ }^{*}$ denote statistical significance at the $1 \%, 5 \%$, and $10 \%$ levels, respectively.

Evidence from Table 4 supports our original hypotheses that stock price crash risk is positively related to labor union. However, the insignificant coefficient of the Institutional Ownership variable (Models 1 and 3 of the same table) and the relatively low significance level of the Analyst Coverage variable (Models 2 and 4 of the same table) require 
further investigations particularly in light with the findings of prior researches supporting the disciplinary roles of these two mechanisms. To this end, we propose to reconsider our analysis for two sub-samples, i.e. firms with high percentage of institutional ownership versus firms with low percentage of institutional ownership $(I O)$. We do the same for the variable Analyst Coverage $(A C O V)$.

We re-run our basic model (Model 1 of Table 3) separately for sub-samples based on the median of institutional ownership. The results for NCSKEW regressions are reported in Models (1) and (2) of Table 5. As we can observe, the coefficient for $U N I O N$ is positive and significant at the $1 \%$ level only for the sub-sample of firms with low institutional ownership, suggesting that the adverse effects of labor union on stock price crash risk are less pronounced in firms with high institutional ownership. This finding is consistent with the monitoring hypothesis of institutional ownership. The results for DUVOL regressions, which are reported in Models (1) and (2) of Table 6 also support this hypothesis.

Table 5. Sub-sample analysis-Set 1

\begin{tabular}{|c|c|c|c|c|c|c|c|c|}
\hline \multirow{5}{*}{ Variable } & \multicolumn{8}{|c|}{ NCSKEW } \\
\hline & \multicolumn{4}{|c|}{$I O_{t-1}$} & \multicolumn{4}{|c|}{$A C O V_{t-1}$} \\
\hline & \multicolumn{2}{|c|}{ High } & \multicolumn{2}{|c|}{ Low } & \multicolumn{2}{|c|}{ High } & \multicolumn{2}{|c|}{ Low } \\
\hline & Coefficient & p-value & Coefficient & p-value & Coefficient & $\mathrm{p}$-value & Coefficient & p-value \\
\hline & \multicolumn{2}{|c|}{ (1) } & \multicolumn{2}{|c|}{$(2)$} & \multicolumn{2}{|c|}{ (3) } & \multicolumn{2}{|c|}{$(4)$} \\
\hline UNIONt-1 & 0.034 & 0.66 & $0.356^{* * *}$ & $<0.01$ & -0.054 & 0.51 & $0.374 * * *$ & $<0.01$ \\
\hline$S I Z E_{t-1}$ & $0.009 * *$ & 0.02 & $0.011 * * *$ & $<0.01$ & 0.001 & 0.24 & -0.005 & 0.14 \\
\hline$N C S K E W_{t-1}$ & $0.031 * * *$ & $<0.01$ & $0.033 * * *$ & $<0.01$ & $0.026 * * *$ & $<0.01$ & $0.038 * * *$ & $<0.01$ \\
\hline$L E V E R A G E_{t-1}$ & -0.049 & 0.17 & -0.007 & 0.82 & -0.006 & 0.53 & 0.004 & 0.66 \\
\hline$M B_{t-1}$ & $0.019 * * *$ & $<0.01$ & $0.012 * * *$ & $<0.01$ & $0.006 * * *$ & $<0.01$ & $0.005^{* * *}$ & $<0.01$ \\
\hline$R O A_{t-1}$ & $0.400 * * *$ & $<0.01$ & $0.207 * * *$ & $<0.01$ & $0.168 * * *$ & $<0.01$ & $0.081 * * *$ & $<0.01$ \\
\hline DTURNOVER $R_{t-1}$ & $0.019 * *$ & 0.02 & $0.034 * * *$ & $<0.01$ & $0.008 * * *$ & $<0.01$ & $0.014 * * *$ & $<0.01$ \\
\hline$R E T_{t-1}$ & $5.574 * * *$ & $<0.01$ & $5.369 * * *$ & $<0.01$ & $2.666^{* * *}$ & $<0.01$ & $2.288 * * *$ & $<0.01$ \\
\hline$S I G M A_{t-1}$ & -0.294 & 0.49 & $-2.156^{* * *}$ & $<0.01$ & -0.111 & 0.97 & $-1.069 * * *$ & $<0.01$ \\
\hline$A Q_{t-1}$ & $0.098^{* * *}$ & $<0.01$ & $0.065 * * *$ & $<0.01$ & $0.035 * * *$ & $<0.01$ & $0.035 * * *$ & $<0.01$ \\
\hline Intercept & -0.193 & & -0.146 & 0.16 & -0.021 & 0.96 & -0.059 & 0.05 \\
\hline Year fixed effect & Yes & & Yes & & Yes & & Yes & \\
\hline Industry fixed effect & Yes & & Yes & & Yes & & Yes & \\
\hline Observations & 36,771 & & 36,772 & & 34,961 & & 38,582 & \\
\hline R-squared & 0.017 & & 0.022 & & 0.018 & & 0.023 & \\
\hline
\end{tabular}

This table presents results of sub-sample analysis of the impact of labor union on stock price crash risk. Models from 1 and 2 report results of $N C S K E W$ regressed on labor union for high and low IO. Models from 3 and 4 report results of NCSKEW regressed on labor union for high and low ACOV. The full sample includes a sample of 73,543 firm-year observations for the 1984-2013 period. All regressions include industry and year dummies to control for industry and year fixed-effects, respectively. Descriptions and data sources for the regression variables are provided in the Appendix. We adjust standard errors for the effect of non-independence by clustering on each firm. ***, **, and * denote statistical significance at the $1 \%, 5 \%$, and $10 \%$ levels, respectively.

As for the second variable Analyst Coverage, we also re-run our basic model (Model 1 of Table 3) separately for sub-samples based on the median of $A C O V$. The results for NCSKEW regressions are reported in Models (3) and (4) of Table 5. They show that the coefficient for UNION is positive and highly significant only for the sub-sample of firms with low $A C O V$, suggesting that the adverse effects of labor union on stock price crash risk are less pronounced in firms with high analyst coverage. This result is consistent with the argument that analyst following helps mitigating information asymmetry problems, hence reduces stock price crash risk. The results for DUVOL regressions, which are reported in Models (3) and (4) of Table 6 also support this hypothesis.

Overall, these results suggest that the adverse effects of labor union on stock price crash risk are less pronounced in firms with high institutional ownership and high analyst coverage, respectively. 
Table 6. Sub-sample analysis_-Set 2

\begin{tabular}{|c|c|c|c|c|c|c|c|c|}
\hline \multirow{5}{*}{ Variable } & \multicolumn{8}{|c|}{ DUVOL } \\
\hline & \multicolumn{4}{|c|}{$I O_{t-1}$} & \multicolumn{4}{|c|}{$A C O V_{t-1}$} \\
\hline & \multicolumn{2}{|c|}{ High } & \multicolumn{2}{|c|}{ Low } & \multicolumn{2}{|c|}{ High } & \multicolumn{2}{|c|}{ Low } \\
\hline & Coefficient & $\mathrm{p}$-value & Coefficient & $\mathrm{p}$-value & Coefficient & p-value & Coefficient & p-value \\
\hline & \multicolumn{2}{|c|}{ (1) } & \multicolumn{2}{|c|}{ (2) } & \multicolumn{2}{|c|}{ (3) } & \multicolumn{2}{|c|}{ (4) } \\
\hline UNIONt-1 & 0.002 & 0.93 & $0.180 * * *$ & $<0.01$ & -0.043 & 0.19 & $0.192 * * *$ & $<0.01$ \\
\hline$S I Z E_{t-1}$ & 0.002 & 0.35 & -0.002 & 0.15 & 0.001 & 0.67 & $-0.005^{* * *}$ & $<0.01$ \\
\hline$D U V O L_{t-1}$ & $0.027 * * *$ & $<0.01$ & $0.039 * * *$ & $<0.01$ & $0.026 * * *$ & $<0.01$ & $0.038 * * *$ & $<0.01$ \\
\hline$L E V E R A G E_{t-1}$ & -0.019 & 0.19 & 0.010 & 0.46 & -0.006 & 0.68 & 0.004 & 0.76 \\
\hline$M B_{t-1}$ & $0.007 * * *$ & $<0.01$ & $0.005^{* * *}$ & $<0.01$ & $0.006 * * *$ & $<0.01$ & $0.005 * * *$ & $<0.01$ \\
\hline$R O A_{t-1}$ & $0.156^{* * *}$ & $<0.01$ & $0.084 * * *$ & $<0.01$ & $0.168 * * *$ & $<0.01$ & $0.081 * * *$ & $<0.01$ \\
\hline$D_{T U R N O V E R_{t-1}}$ & $0.007 * * *$ & $<0.01$ & $0.014 * * *$ & $<0.01$ & $0.008 * * *$ & $<0.01$ & $0.014 * * *$ & $<0.01$ \\
\hline$R E T_{t-1}$ & $2.068 * * *$ & $<0.01$ & $2.486^{* * *}$ & $<0.01$ & $2.666^{* * *}$ & $<0.01$ & $2.288 * * *$ & $<0.01$ \\
\hline$S I G M A_{t-1}$ & -0.191 & 0.27 & $-1.158 * * *$ & $<0.01$ & -0.111 & 0.55 & $-1.069^{* * *}$ & $<0.01$ \\
\hline$A Q_{t-1}$ & $0.042 * * *$ & $<0.01$ & $0.032 * * *$ & $<0.01$ & $0.035 * * *$ & $<0.01$ & $0.035 * * *$ & $<0.01$ \\
\hline Intercept & -0.098 & 0.05 & -0.011 & & -0.021 & 0.64 & -0.059 & 0.20 \\
\hline Year fixed effect & Yes & & Yes & & Yes & & Yes & \\
\hline $\begin{array}{l}\text { Industry fixed } \\
\text { effect }\end{array}$ & Yes & & Yes & & Yes & & Yes & \\
\hline Observations & 36771 & & 36772 & & 34961 & & 38582 & \\
\hline R-squared & 0.015 & & 0.024 & & 0.018 & & 0.023 & \\
\hline
\end{tabular}

This table presents results of sub-sample analysis of the impact of labor union on stock price crash risk. Models from 1 and 2 report results of $D U V O L$ regressed on labor union for high and low $I O$. Models from 3 and 4 report results of DUVOL regressed on labor union for high and low ACOV. The full sample includes a sample of 73,543 firm-year observations for the 1984-2013 period. All regressions include industry and year dummies to control for industry and year fixed-effects, respectively. Descriptions and data sources for the regression variables are provided in the Appendix. We adjust standard errors for the effect of non-independence by clustering on each firm. ***, **, and * denote statistical significance at the $1 \%, 5 \%$, and $10 \%$ levels, respectively.

\section{Conclusion}

In contributing to the literature on the importance of nonfinancial stakeholders for corporate decisions and economic outcomes (e.g., Hillary, 2006; Klasa et al., 2006; Chen, Kacperczyk, and Ortiz-Molina 2011, 2012; Chen, Chen, and Liao 2011; Bova, 2013; Chung et al., 2014, among others), we choose to focus on the relationship between labor unions and stock price crash risk. Specifically, using a large sample of U.S. firms over the period 1984-2014, we show that stock price crash risk is increasing in labor union strength. This finding is consistent with the conjecture that firms facing strong labor unions tend to report lower accounting information, in order to preserve bargaining power when negotiating contracts, which lead to opaque financial reporting and increases the likelihood to experience stock price crash. We also find that the adverse effects of labor union on stock price crash risk are less pronounced for firms with strong external monitoring mechanisms, such as high institutional ownership and high analyst coverage.

Overall, our study sheds the light on the importance of the previously under-explored role of labor unions in relation to the stock price crash risk. While the present paper highlights the importance of labor unions as nonfinancial player for stock price crash risk, future researches can examine the impact of other nonfinancial shareholders such as customers and suppliers on stock price crash risk.

\section{Acknowledgement}

We would like to thank the Deanship of Scientific Research at King Saud University, represented by the research center at CBA, for supporting this research financially. 


\section{References}

Acharya, V.V., R.P. Baghai, \& K.V. Subramanian. (2010). Labor laws and innovation, NBER Working Paper No. 16484.

An, H., \& T. Zhang. (2013). Stock price synchronicity, crash risk, and institutional investors. Journal of Corporate Finance 21, 1-15. http://dx.doi.org/10.1016/j.jcorpfin.2013.01.001

Atanassov, J., \& E.H. Kim. (2009). Labor laws and corporate governance: International evidence from restructuring decisions. Journal of Finance, 64, 341-374. http://dx.doi.org/10.1111/j.1540-6261.2008.01436.x

Ball, R., \& L. Shivakumar. (2005). Earnings quality in UK private firms: Comparative loss recognition. Journal of Accounting and Economics, 38, 83-128. http://dx.doi.org/10.1016/j.jacceco.2004.04.001

Bova, F. (2013). Labor unions and management's incentive to signal a negative outlook. Contemporary Accounting Research, 30, 14-41. http://dx.doi.org/10.1111/j.1911-3846.2012.01160.x

Bowen, R., L. Ducharme, \& D. Shores. (1995). Stakeholders' implicit claims and accounting method choice. Journal of Accounting and Economics, 20, 225-294. http://dx.doi.org/10.1016/0165-4101(95)00404-1

Callen, J.L., \& X. Fang. (2013). Institutional investor stability and crash risk: monitoring versus short-termism. Journal of Banking and Finance, 37, 3047-3063. http://dx.doi.org/10.1016/j.jbankfin.2013.02.018

Chen, H.J. M. Kacperczyk, \& H. Ortiz-Molina. (2011). Labor unions, operating flexibility, and the cost of equity. Journal of Financial and Quantitative Analysis, 46, 25-58.

Chen, H.J. M. Kacperczyk, \& H. Ortiz-Molina. (2012). Do nonfinancial stakeholders affect the pricing of risky debt? Evidence from unionized workers. Review of Finance, 16, 347-383.

Chen, J., H. Hong, \& J.C. Stein. (2001). Forecasting crashes: trading volume, past returns, and conditional skewness in stock prices. Journal of Financial Economics, 61, 345-381.

Chen, Y-S., \& I-J. Chen. (2013). The impact of labor unions on investment-cash flow sensitivity. Journal of Banking and Finance, 37, 2408-2418. http://dx.doi.org/10.1016/j.jbankfin.2013.02.001

Chung, Richard, Lee, Bryan Byung-Hee, Lee, Woo-Jong, \& Sohn, Byungcherl Charlie. (2014, September). Do Managers Withhold Good News from Labor Unions?. Management Science, Forthcoming. http://dx.doi.org/10.2139/ssrn.1927185

Cullinan, C., \& D. Bline. (2003). The effects of labour and accounting choice in Canada. Canadian Accounting Perspect, 2, 135-51.

D'Souza, J., J. Jacob, \& K. Ramesh. (2000). The use of accounting flexibility to reduce labor renegotiation costs and manage earnings. Journal of Accounting and Economics, 30, 187- 208.

DeAngelo, H., \& L. DeAngelo. (1991). Union negotiations and corporate policy: A study of labor concessions in the domestic steel industry during the 1980s. Journal of Financial Economics, 30, 3-43.

Dechow, P.M., \& I.D. Dichev. (2002). The Quality of Accruals and Earnings: The Role of Accruals Estimation Errors. Accounting Review, 77, 35-59.

DeFond, M., S. Hung, \& Y. Li. (2012). Does Mandatory IFRS Adoption Affect Crash Risk? Working paper, University of Southern California.

Faleye, O., V. Mehrotra, \& R. Morck. (2006). When labor has a voice in corporate governance. Journal of Financial and Quantitative Analysis, 41, 489-510.

Farber, David B., Hsieh, Hsin-Yi (Shirley), Jung, Boochun, \& Yi, Han. (2012, February). The Impact of Non-Financial Stakeholders on Accounting Conservatism: The Case of Labor Unions. http://dx.doi.org/10.2139/ssrn.2001940

Hamm, S J.W., B. Jung, \& W.J. Lee. (2013). Labor unions and income smoothing, Working paper, The Ohio State University.

Hilary, G. (2006). Organized Labor and Information Asymmetry in the Financial Markets. Review of Accounting Studies, 11, 525-548. http://dx.doi.org/10.1007/s11142-006-9015-y

Hirsch, B., \& D. Macpherson. (2003). Union membership and coverage database from the Current Population Survey: Note. Industrial and Labor Relations Review, 56, 349-54. 
Hirsch, B.T. (1980). The determinants of unionization: An analysis of interarea differences. Industrial and Labor Relations Review, 33, 147-161.

Hirsch, B.T. (2008). Sluggish Institutions in a Dynamic World: Can Unions and Industrial Competition Coexist? Journal of Economic Perspectives, 22, 153-176.

Hutton, A.P., A.J. Marcus, \& H. Tehranian. (2009). Opaque Financial Reports, R2, and Crash Risk. Journal of Financial Economics, 94, 67-86. http://dx.doi.org/10.1016/j.jfineco.2008.10.003

Jin, L., \& S.C. Myers. (2006). R2 around the World: New Theory and New Tests. Journal of Financial Economics, 79 , 257-292. http://dx.doi.org/10.1016/j.jfineco.2004.11.003

Kim, J.-B., \& L., Zhang. (2013). Accounting Conservatism and Stock Price Crash Risk: Firm-Level Evidence. Contemporary Accounting Research, Forthcoming.

Kim, J.-B., Y. Li, \& L. Zhang. (2011a). Corporate Tax Avoidance and Stock Price Crash Risk: Firm-Level Analysis. Journal of Financial Economics, 100, 639-662. http://dx.doi.org/10.1016/j.jfineco.2010.07.007

Kim, J.-B., Y. Li, \& L. Zhang. (2011b). CFOs Versus CEOs: Equity Incentives and Crashes. Journal of Financial Economics, 101, 713-730. http://dx.doi.org/10.1016/j.jfineco.2011.03.013

Kim, Y., Li, H., \& S. Li. (2014). Corporate social responsibility and stock price crash risk. Journal of Banking and Finance, 43, 1-13. http://dx.doi.org/10.1016/j.jbankfin.2014.02.013

Klasa, S., W.F., Maxwell, \& H. Ortiz-Molina. (2009). The strategic use of corporate cash holdings in collective bargaining with labor unions. Journal of Financial Economics, 92, 421-442. http://dx.doi.org/10.1016/j.jfineco.2008.07.003

Serfling, M.A. (2013). Labor adjustment costs and capital structure decisions. Working paper, University of Arizona.

Notes

Note 1. The database is available at http://www.unionstats.com. See Hirsch and Macpherson (2003) for a description of the approach used to construct this database.

Note 2. Labor union data is available starting from 1983. That's why, we estimate stock price crash risk proxies over the period that starts in 1983. Our final sample covers the period between 1984-2013. We lose observations for 1983 because of the need to control in all our regression for our lagged labor union proxy. 
Appendix

Variables, Descriptions, and Sources

\begin{tabular}{|c|c|c|}
\hline Variable & Description & Source \\
\hline NCSKEW & $\begin{array}{l}\text { The negative coefficient of skewness calculated by taking the negative of the third moment } \\
\text { of firm firm-specific weekly returns for each sample year divided by the standard deviation } \\
\text { of firm-specific weekly returns raised to the third power. See equation (2) for details. }\end{array}$ & $\begin{array}{l}\text { Authors' } \\
\text { calculation }\end{array}$ \\
\hline DUVOL & $\begin{array}{l}\text { The down-to-up volatility calculated as the natural logarithm of the standard deviation of } \\
\text { weekly-stock returns during the weeks in which they are lower than their annual mean } \\
\text { ("down" weeks) over the standard deviation of weekly-stock returns during the weeks in } \\
\text { which they are higher than their annual mean ("up" weeks). }\end{array}$ & $\begin{array}{l}\text { Authors' } \\
\text { calculation }\end{array}$ \\
\hline UNION & $\begin{array}{l}\text { The firm-year unionization rate is calculated by multiplying the industry-level unionization } \\
\text { rate by the number of employees deflated by total assets. Industry-level unionization rates } \\
\text { come from Hirsch and Macpherson (2003)'s updated database of Union Membership and } \\
\text { Coverage. }\end{array}$ & $\begin{array}{l}\text { Authors' } \\
\text { calculation } \\
\text { calculation }\end{array}$ \\
\hline SIZE & The natural logarithm of the firm's market value. & $\begin{array}{l}\text { Authors' } \\
\text { calculation }\end{array}$ \\
\hline$L E V E R A G E$ & The ratio of long-term debt over total assets. & $\begin{array}{l}\text { Authors' } \\
\text { calculation }\end{array}$ \\
\hline$M B$ & The market-to-book ratio. & $\begin{array}{l}\text { Authors' } \\
\text { calculation }\end{array}$ \\
\hline ROA & The ratio of net income over total assets. & $\begin{array}{l}\text { Authors' } \\
\text { calculation }\end{array}$ \\
\hline $\begin{array}{l}\text { DTURNOVE } \\
R\end{array}$ & $\begin{array}{l}\text { The difference between the average monthly turnover at the end of the year and the average } \\
\text { monthly turnover at the beginning of the year. }\end{array}$ & $\begin{array}{l}\text { Authors' } \\
\text { estimation }\end{array}$ \\
\hline$R E T$ & The average of firm-specific weekly returns over the fiscal year. & $\begin{array}{l}\text { Authors' } \\
\text { calculation }\end{array}$ \\
\hline SIGMA & The standard deviation of the weekly stock returns over the fiscal year. & $\begin{array}{l}\text { Authors' } \\
\text { calculation }\end{array}$ \\
\hline$A Q$ & $\begin{array}{l}\text { The absolute value of Dechow and Dichev's (2002) measure of abnormal accruals, as } \\
\text { modified by Ball and Shivakumar (2005). }\end{array}$ & $\begin{array}{l}\text { Authors' } \\
\text { calculation }\end{array}$ \\
\hline$I O$ & The fraction of the firm's shares held by institutional investors. & $\begin{array}{l}\text { Authors' } \\
\text { calculation }\end{array}$ \\
\hline$A C O V$ & The natural logarithm of one plus the number of analysts following a firm. & $\mathrm{I} / \mathrm{B} / \mathrm{E} / \mathrm{S}$ \\
\hline
\end{tabular}

